\title{
Effects of Container and Duration of Storage on the Quality of Okra (Abelmoschus esculentus) Seeds
}

\author{
Razia Sultana*, M. Salahuddin M. Chowdhury, Md. Rafiqul Islam and Khadija Akhter \\ Department of Plant Pathology, Sher-e-Bangla Agricultural University, Dhaka-1207, Bangladesh \\ *Corresponding author and Email: raziasultana.sau52@gmail.com
}

Received: 14 December $2015 \quad$ Accepted: 12 June 2016

\begin{abstract}
A study was conducted in the laboratory of the Department of Seed Pathology, Sher-e-Bangla Agricultural University, Bangladesh during July 2013 to June 2014 to determine the effects of different storage containers and durations of storage on the quality of okra (Abelmoschus esculentus) seeds and seedling growth. After harvest, seeds were stored in earthen pots, plastic pots, plastic bags, gunny bags with and without polyethylene lining for the periods of 4, 8, and 12 months. The seeds stored in plastic container showed the lowest moisture content $(8.03 \%)$ at 4 months of storage and those stored in gunny bag showed the maximum moisture content $(17.63 \%)$ at 12 months of storage. Percentage of seeds infested with fungi was minimum in plastic container, where the prevalence of Fusarium spp., Chaetomium globosum, Aspergillus flavus, Aspergillus niger, Rhizopus stolonifer and Curvularia spp. were $1.47,8.03,3.31,3.31,2.57$ and $3.53 \%$, respectively at 4 months of storage. Prevalence of fungi was maximum in seeds stored in gunny bag where the prevalence of Fusarium spp., Chaetomium globosum, Aspergillus flavus, Aspergillus niger, Rhizopus stolonifer and Curvularia spp. were 4.87, $17.63,4.41,5.97,84.86$ and $5.19 \%$, respectively at 12 months of storage. In contrast, treated seeds stored in plastic container showed the maximum germination $(94.74 \%)$, longest shoot $(20.76 \mathrm{~cm})$ and root $(11.52 \mathrm{~cm})$, highest seed vigor index (3087.00), highest weight of dry seedlings $(55.60 \mathrm{~g})$ at 4 months of storage. However, seeds stored in gunny bag showed the lowest seed germination (45.08\%), shoot length $(11.49 \mathrm{~cm})$, root length $(6.34 \mathrm{~cm})$, seedling vigor index $(838.10)$, dry weight of seedlings $(33.40 \mathrm{~g})$ and field emergence $(37.36 \%)$ at 12 months of storage. Plastic containers appeared to be the best for storage of okra seeds.
\end{abstract}

Keywords: Okra, Seed borne fungi, seed vigor, seed germination, storage

\section{Introduction}

Okra Abelmoschus esculentus (L.) Moench is an important vegetable crop grown mainly in the tropical or sub-tropical regions during summer and rainy season. The major okra producing countries in the world are India (3.5 million tons), Nigeria (0.73 million tons), Pakistan (0.12 million tons), Ghana (0.10 million tons) and Egypt (0.08 million tons) (Nwangburuka, 2010; Badaru, 2011). In Bangladesh, it is grown round the year but its production is mainly concentrated during summer season. In the country, okra is grown in about 10500 hectares of land with an average yield of 2.67 ton per hectare and the total production is 43,000 metric tons (Anonymous, 2012). 
It is a nutritious vegetable containing $86.1 \%$ water, $2.2 \%$ protein, $0.2 \%$ fat, $9.7 \%$ carbohydrate, $1 \%$ fiber and $0.8 \%$ ash (Anonymous, 2010). Gopalan et al. (2007) reported that in $100 \mathrm{~g}$ of okra seeds contains $35.0 \mathrm{~g}$ calories, $6.4 \mathrm{~g}$ carbohydrates, $1.9 \mathrm{~g}$ protein, $0.2 \mathrm{~g}$ fat, $1.2 \mathrm{~g}$ fiber, $0.7 \mathrm{~g}$ minerals, $56.0 \mathrm{mg}$ phosphorus, $6.9 \mathrm{mg}$ sodium, $30.0 \mathrm{mg}$ sulphur, $66.0 \mathrm{mg}$ calcium, $0.35 \mathrm{mg}$ iron, $103.0 \mathrm{mg}$ potassium, $53.0 \mathrm{mg}$ magnesium, $0.19 \mathrm{mg}$ copper and $8.0 \mathrm{mg}$ oxalic acid. The edible portion of the fruit, on an average, contains approximately; $86.1 \%$ moisture, $9.7 \%$ Riboflavin, $0.01 \mathrm{mg}$ carbohydrates, $2.2 \%$ protein, $1.0 \%$ fibers, $0.2 \%$ fats and $0.9 \%$ ash.

The crop losses have been attributed to various reasons such as the use of unhealthy seeds, adverse agro climatic conditions, pathogenic status, etc. Recent studies indicated greater loss in the yield mainly due to pathogenic attack. Lots of efforts are hence being put to improve the growth of okra plants and yield of fruits. Okra is attacked by several fungal pathogens, which not only reduces the potency of seed, but also degrades the health beneficial and nutritional quality components (Anonymous, 2003). Further, seeds obtained in monsoon/summer have to be stored prior to its usage in the next season. Indeed the storage becomes very crucial to avail the benefit of okra (Anonymous, 2003).

Aktaruzzaman et al. (2010) reported that the storage container also influenced on the quality of okra seeds. He found that, above three containers- sealed container, polythene bag and gunny bag from them sealed container is the best one for storage of seeds. The effect of packaging materials on moisture contents of okra (Abelmoschus esculentus) was studied by Fabunmi (2009) during storage at room $(28+/-$ $\left.2^{\circ} \mathrm{C}\right)$ and refrigerating condition $\left(15+/-2^{\circ} \mathrm{C}\right)$ using three different packages (open plastic bowl as control, plastic sieve over-wrapped with low density polyethylene bags, and low density polyethylene bags (LDPE) $-15 \times 15 \mathrm{~cm}$. The results showed that packaging materials had a significant effect on moisture content where okra stored in polyethylene followed by plastic sieve container controlled moisture content. Begum et al. (2005) reported that the okra variety Arka Anamika although a most popular, high yielding variety in India, it is susceptible to several fungal pathogens which results in the reduction of yield and nutritional quality. Healthy, moderately and severely infected seeds obtained from local market were evaluated for their storability for a year using different storage containers (cotton bag, polyethylene and paper bags) at varied temperatures. Biochemical parameters as well as pathogenic status were evaluated as a measure of seed quality. Results indicated that the moisture content play a key role in amplifying fungal biomass during storage period. Cotton bag at $28^{\circ} \mathrm{C}$ appeared to be the best suited for long storage of seeds. Thus stored seeds showed significant germination efficiency, seedling vigor without further deterioration of its biochemical constituents. With respect to fluctuation in moisture content cotton bags offer greater protection than that of polyethylene or paper bags.

The present study was undertaken to observe the effect of storage containers and duration of storage period on seed quality and prevalence of seed-borne fungi of okra seeds.

\section{Materials and Methods}

The study was conducted in the laboratory of the Department of Seed Pathology, Sher-e-Bangla Agricultural University, Bangladesh during July 2013 to June 2014. The experiment was laid out in a factorial randomized complete design with three replicates. The okra variety BARI Dherosh-1 was used as experimental materials. The experiment comprised of five containers namely: plastic pot, plastic bag, polythene coated gunny bag, gunny bag without polyethylene coat and earthen pot. These were stored for the periods of 4,8 , and 12 months.

Okra seeds were poured into the containers and placed on the laboratory desk at ambient conditions for the observation of seed quality and incidence of fungi in storage condition for 
different durations of storage. Seedling attributes after germination were also evaluated in Plant Pathology Laboratory. Six fungal species, Fusarium spp., Chaetmium globosum, Aspergilus flavus, Aspergilus niger, Rhizopus stolonifer and Curvularia spp. were recorded at 4, 8 and 12 months of storage.

Moisture content of the seed samples were determined prior to storage and the results were expressed in percentage on wet weight basis and germination was determined using Paper Towel Method (ISTA, 2006). Final count was observed on $12^{\text {th }}$ day and 10 normal seedlings were selected randomly and their root and shoot lengths were measured. Vigor index was calculated using the formula of Baki and Anderson (1973) as shown below:

Vigor index $=$ Germination $(\%) \mathrm{X}$ (Mean shoot length + mean root length)

Ten normal seedlings were used for measuring the dry weight of seedlings. The field emergence count was taken on $15^{\text {th }}$ day of sowing in the seed bed. The seedlings appearing on the surface of soil were considered as emerged. The field emergence values were expressed in percentage. Seed health in terms of fungi associated with okra seeds were tested following International Rules for Seed Health Testing using both Blotter and Paper Towel Method. The minimum and maximum temperatures of the storage room during the study period were 24.0 and $33.5^{\circ} \mathrm{C}$, respectively. The minimum and maximum relative humidity was 65 and $98 \%$, respectively.

The data of all tests were analyzed statistically for analysis of variance using MSTAT-C computer program. The means were compared for difference using Duncan's Multiple Range Test or least significant difference at $0.5 \%$ level of significance. Whenever necessary the data were transformed before statistical analysis following appropriate method.

\section{Results and Discussion 3.1. Effect on moisture content}

The differences in moisture content were significant for the different containers. The effect of storage containers on moisture content of seeds was considerable ranging from 8.03 to $17.63 \%$ at 4,8 and 12 months of storage. Seeds stored in gunny bag showed the highest moisture contents (16.40, 16.44 and $17.63 \%)$ followed by earthen pot (16.10, 16.16 and 16.84). The moisture content was the minimum when seeds were stored in plastic pots followed by plastic bag (Table 1).

\subsection{Effect on germination}

Germination of stored okra seeds decreased gradually with increase storage period in all containers with the lowest germination after 12 months. The effect of storage containers on germination was significant over different storage periods. At 4, 8 and 12 months of storage, seeds stored in plastic container showed the highest germination $(94.74,90.97$ and $86.64 \%$ ) followed by plastic bag $(94.59,90.75$ and $86.62 \%$ ). The lowest germination was recorded from seeds stored in gunny bag without lining, followed by earthen pot and gunny bag with lining (Table 1).

\subsection{Effect on shoot and root length of seedlings}

Shoot and root lengths of seedlings of okra decreased with the progress of storage period of seeds. The highest shoot and root lengths were recorded when seeds were stored in plastic pots followed by plastic bags. Lower shoot and root length were obtained when seeds were stored in earthen pot or gunny bag without polyethylene lining compared to gunny bag with lining (Table 2).

\subsection{Vigor index and dry weight of seedling}

Seedling vigor index and dry weight of okra seedlings decreased with the increase of storage period in all storage containers. Seeds stored in plastic pots showed the highest seedling vigor index (3087.00, 2425.0 and 2173.0) followed by plastic bag (2972, 2384 and 2119) at 4, 8 and 12 months of storage. The lowest vigor index and dry weight of seedling were recorded from seeds stored in gunny bags without lining. The highest dry weight of seedlings was obtained when seeds 
were stored in plastic pots as well as plastic bag at 4,8 and 12 months of storage. Results of the present study show that seeds stored in gunny bag yielded the lowest field emergence, less vigorous seedlings than the other storage containers at different months of storage (Table $3)$.

Table 1. Effect of different storage containers on percentage of moisture content and germination of okra from the seed of different months of storage

\begin{tabular}{|c|c|c|c|c|c|c|}
\hline \multirow[t]{2}{*}{ Treatments } & \multicolumn{3}{|c|}{$\begin{array}{c}\text { Moisture content }(\%) \text { at different months of } \\
\text { storage }\end{array}$} & \multicolumn{3}{|c|}{$\begin{array}{c}\text { Germination (\%) at different months of } \\
\text { storage }\end{array}$} \\
\hline & 4 & 8 & 12 & 4 & 8 & 12 \\
\hline $\mathrm{T}_{1}(\mathrm{pc})$ & $8.03 \mathrm{e}$ & $8.21 \mathrm{e}$ & $8.56 \mathrm{~d}$ & $94.74 \mathrm{a}$ & $90.97 \mathrm{a}$ & $86.64 \mathrm{a}$ \\
\hline $\mathrm{T}_{2}(\mathrm{pb})$ & $8.21 \mathrm{~d}$ & $8.34 \mathrm{~d}$ & $8.64 \mathrm{~d}$ & $94.59 \mathrm{a}$ & $90.75 \mathrm{a}$ & $86.62 \mathrm{a}$ \\
\hline $\mathrm{T}_{3}(\mathrm{pgb})$ & $14.19 \mathrm{c}$ & $14.32 \mathrm{c}$ & $14.97 \mathrm{c}$ & $75.09 \mathrm{~b}$ & $74.73 \mathrm{~b}$ & $54.19 \mathrm{~b}$ \\
\hline $\mathrm{T}_{4}(\mathrm{gb})$ & $16.40 \mathrm{a}$ & $16.44 \mathrm{a}$ & $17.63 \mathrm{a}$ & $69.58 \mathrm{c}$ & $62.85 \mathrm{c}$ & $45.08 \mathrm{c}$ \\
\hline $\mathrm{T}_{5}(\mathrm{ep})$ & $16.10 \mathrm{~b}$ & $16.16 \mathrm{~b}$ & $16.84 \mathrm{~b}$ & $69.69 \mathrm{c}$ & $63.06 \mathrm{c}$ & $45.21 \mathrm{c}$ \\
\hline $\operatorname{LSD}(5 \%)$ & 0.1218 & 0.1255 & 0.1362 & 1.219 & 1.168 & 0.9334 \\
\hline $\mathrm{CV}$ & 1.00 & 1.02 & 1.05 & 1.57 & 1.59 & 1.53 \\
\hline
\end{tabular}

Pc: Plastic container; Pb: Plastic bag; Pgb: Polythene coated gunny bag; Gb: Gunny bag and Ep: Earthen pot

Table 2. Effect of storage containers and periods on the shoot and root length of okra seedlings

\begin{tabular}{lllllll}
\hline \multirow{2}{*}{ Treatments } & \multicolumn{3}{c}{$\begin{array}{c}\text { Shoot length of seedling at different } \\
\text { months of storage }\end{array}$} & \multicolumn{3}{c}{$\begin{array}{c}\text { Root length of seedling at different } \\
\text { months of storage }\end{array}$} \\
\cline { 2 - 7 } & 4 & 8 & 12 & 4 & 8 & 12 \\
\hline $\mathrm{T}_{1}(\mathrm{pc})$ & $20.76 \mathrm{a}$ & 17.87 & $14.97 \mathrm{a}$ & $11.52 \mathrm{a}$ & $9.83 \mathrm{a}$ & $8.51 \mathrm{a}$ \\
$\mathrm{T}_{2}(\mathrm{pb})$ & $20.69 \mathrm{a}$ & 17.59 & $14.89 \mathrm{a}$ & $11.42 \mathrm{a}$ & $9.64 \mathrm{~b}$ & $8.11 \mathrm{a}$ \\
$\mathrm{T}_{3}(\mathrm{pgb})$ & $15.74 \mathrm{~b}$ & 12.28 & $11.84 \mathrm{~b}$ & $8.68 \mathrm{~b}$ & $6.59 \mathrm{c}$ & $6.52 \mathrm{~b}$ \\
$\mathrm{~T}_{4}(\mathrm{gb})$ & $15.15 \mathrm{~d}$ & 12.19 & $11.49 \mathrm{c}$ & $8.36 \mathrm{c}$ & $6.48 \mathrm{c}$ & $6.34 \mathrm{~b}$ \\
$\mathrm{~T}_{5}(\mathrm{ep})$ & $15.43 \mathrm{c}$ & 12.3 & $11.69 \mathrm{~b}$ & $8.53 \mathrm{bc}$ & $6.54 \mathrm{c}$ & $6.36 \mathrm{~b}$ \\
\hline $\mathrm{LSD}_{(0.05)}$ & 0.2455 & 0.1552 & 0.1552 & 0.1877 & 0.146 & 0.7432 \\
$\mathrm{CV}(\%)$ & 1.45 & 1.12 & 1.25 & 2.01 & 1.92 & 10.77 \\
\hline
\end{tabular}

(Pc: Plastic container; Pb: Plastic bag; Pgb: Polythene coated gunny bag; Gb: Gunny bag and Ep: Earthen pot)

Table 3. Effect of storage containers and periods on the vigor index and dry weight of okra seedlings

\begin{tabular}{lllllll}
\hline \multirow{2}{*}{ Treatments } & \multicolumn{3}{l}{$\begin{array}{l}\text { Seedling vigor index at different months } \\
\text { of storage }\end{array}$} & \multicolumn{3}{c}{ Dry weight of seedling at different months } \\
& \multicolumn{3}{c}{ of storage } \\
\cline { 2 - 7 } & 4 & 8 & 12 & 4 & 8 & 12 \\
\hline $\mathrm{T}_{1}(\mathrm{pc})$ & $3087.0 \mathrm{a}$ & $2425.0 \mathrm{a}$ & $2173.0 \mathrm{a}$ & $55.60 \mathrm{a}$ & $48.97 \mathrm{a}$ & $42.56 \mathrm{a}$ \\
$\mathrm{T}_{2}(\mathrm{pb})$ & $2972.0 \mathrm{~b}$ & $2384.0 \mathrm{~b}$ & $2119.0 \mathrm{~b}$ & $55.59 \mathrm{a}$ & $48.73 \mathrm{a}$ & $42.51 \mathrm{a}$ \\
$\mathrm{T}_{3}(\mathrm{pgb})$ & $1859.0 \mathrm{c}$ & $1394.0 \mathrm{c}$ & $1030.0 \mathrm{c}$ & $45.56 \mathrm{~b}$ & $34.57 \mathrm{~b}$ & $33.39 \mathrm{~b}$ \\
$\mathrm{~T}_{4}(\mathrm{gb})$ & $1492.0 \mathrm{~d}$ & $1261.0 \mathrm{~d}$ & $838.10 \mathrm{~d}$ & $44.77 \mathrm{~b}$ & $33.71 \mathrm{~b}$ & $33.40 \mathrm{~b}$ \\
$\mathrm{~T}_{5}(\mathrm{ep})$ & $1523.0 \mathrm{~d}$ & $1278.0 \mathrm{~d}$ & $851.50 \mathrm{~d}$ & $45.18 \mathrm{~b}$ & $34.40 \mathrm{~b}$ & $33.66 \mathrm{~b}$ \\
\hline $\mathrm{LSD}_{(0.05)}$ & 67.09 & 35.74 & 28.45 & 2.096 & 3.38 & 2.762 \\
$\mathrm{CV}(\%)$ & 3.19 & 2.13 & 2.11 & 4.41 & 8.76 & 7.73 \\
\hline
\end{tabular}

(Pc: Plastic container; Pb: Plastic bag; Pgb: Polythene coated gunny bag; Gb: Gunny bag and Ep: Earthen pot) 


\subsection{Field emergence of seedling}

Seeds stored in plastic containers gave the maximum field emergence of $88.78,85.25$ and $80.28 \%$ which were followed by plastic bag (87.87, 84.67 and $79.76 \%)$ at 4,8 and 12 months of storage, respectively (Figure 1).

Khalekuzzaman et al. (2012) also found that moisture content, 1000-seed weight, number of abnormal seedlings, seed rot infestation, and fungi association were increased, but germination and number of normal seedlings were decreased with the increase of storage periods. These authors found that among the three containers, tin container was the best for storage of French bean seeds up to 60 days which is in agreement with our findings.

Manira et al. (2012) found that cloth bag was not safe for soybean seed storage for long time than tin container and polythene bag. This was because the rate of moisture absorbance was higher in cloth bag than in tin container and polythene bag.

Begum et al. (2005) reported that the moisture content play a key role in amplifying fungal biomass during storage period. Cotton bag at a temperature of $28^{\circ} \mathrm{C}$ appeared to be the best for long time storage of seeds as these seeds showed significant germination efficiency, seedling vigor without further deterioration of its biochemical constituents. With respect to fluctuation in moisture content, cotton bags offer greater protection than polyethylene or paper bags.

\subsection{Prevalence of seed borne fungi}

Aspergillus flavus, A. niger, Chaetomium globosum, Fusarium spp. and Rhizopus stolonifer were found to be associated with okra seeds stored in different containers. Their prevalence varied with storage containers. Fakir (2001) and Jamandar et al. (2001) reported similar fungi association with okra seeds. Seeds stored in gunny bag showed the highest prevalence of A. flavus (6.52, 7.03 and $8.13 \%)$ as well as $A$. niger $(6,730,7.024$ and $7.85 \%$ ) followed by seeds stored in earthen pot
(5.87, 6.76 and $8.28 \%$ ) at 4,8 and 12 months of storage, respectively (Figures 2 and 3). Islam (2006) found that the prevalence of A. flavus and $A$. niger was the minimum when stored in tin container, while maximum infection was found when stored in gunny bag for one month. Seeds stored in gunny bags showed the highest prevalence of $C$. globosum (16.40, 16.44 and $17.63 \%$ followed by earthen pot $(16.10,16.16$ and $16.84 \%$ ) at 4,8 and 12 months of storage (Figure 4).

Effect of storage containers and periods on prevalence of Curvularia spp. of okra seeds are presented in Figure 5. The highest prevalence of Curvularia spp (3.90, 4.81 and 5.19\%) was recorded for seeds stored in gunny bag followed by earthen pot $(3.69,4.26$ and $4.62 \%)$ at 4,8 and 12 months of storage. Seeds stored in plastic container yielded minimum prevalence of the fungus. Similar findings have been reported by Islam (2006). Seeds stored in gunny bag without lining yielded the highest prevalence of Fusarium spp. (4.02, 4.16 and $4.87 \%$ ) followed by earthen pot $(3.49,3.58$ and $4.33 \%)$ at 4,8 and 12 months of storage (Figure 6).

Effect of storage containers and periods on prevalence of Rhizopus stolonifer of okra seeds are presented in Figure 7. Maximum prevalence (4.27 and $5.79 \%$ ) was found in seeds stored in gunny bag followed by earthen pot (4.16 and $5.12)$ at 4 and 12 months of storage. The effects of earthen pot and gunny bag were not significant. The prevalence of $R$. stolonifer was minimum when seeds were stored in plastic container. Similar results were reported by Islam (2006). Malaker et al. (2008) found that the highest germination percentage was observed under storage in refrigerator followed by polyethylene bag, tin container and earthen pitcher. Moisture content increased and seed germination decreased with the increase of storage period. Various fungal flora associated with wheat seeds differed in their prevalence depending on the length of storage period and types of container used for storage, which is similar to that in the present result. 


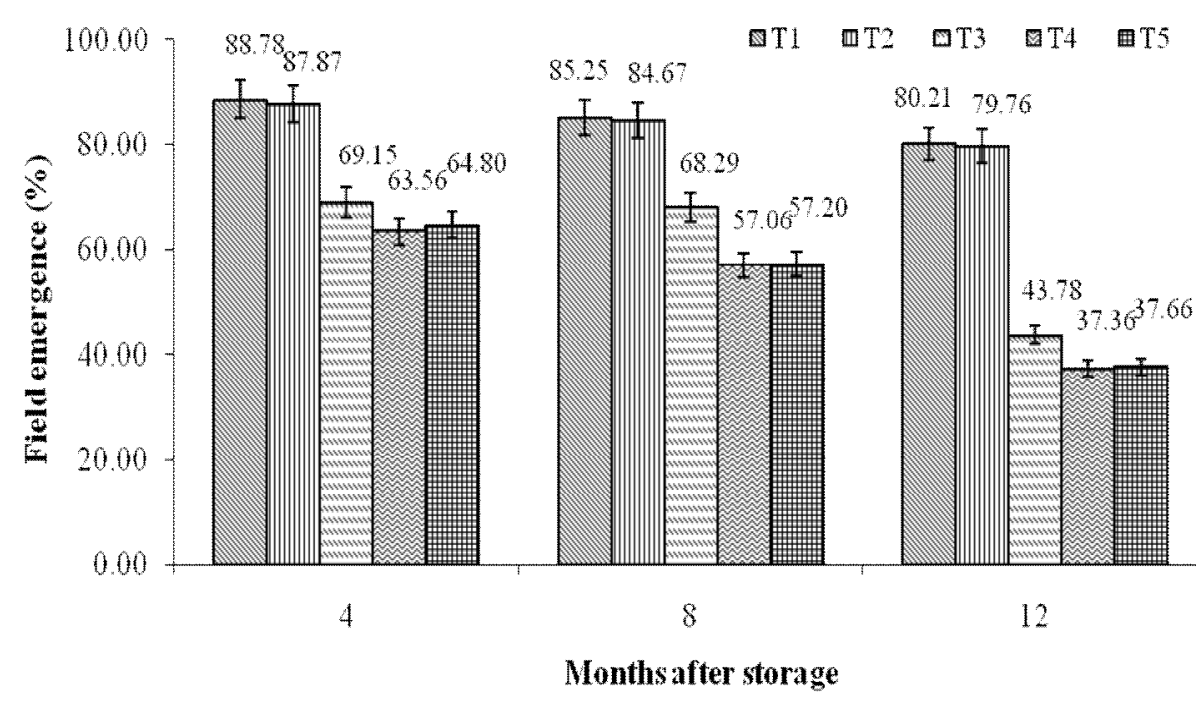

( $\mathrm{T}_{1}$ : Plastic container; $\mathrm{T}_{2}$ : Plastic bag; $\mathrm{T}_{3}$ : Polythene coated gunny bag; $\mathrm{T}_{4}$ : Gunny bag and $\mathrm{T}_{5}$ : Earthen pot)

Figure 1. Effect of storage containers on field emergence of okra seedlings at different months of storage

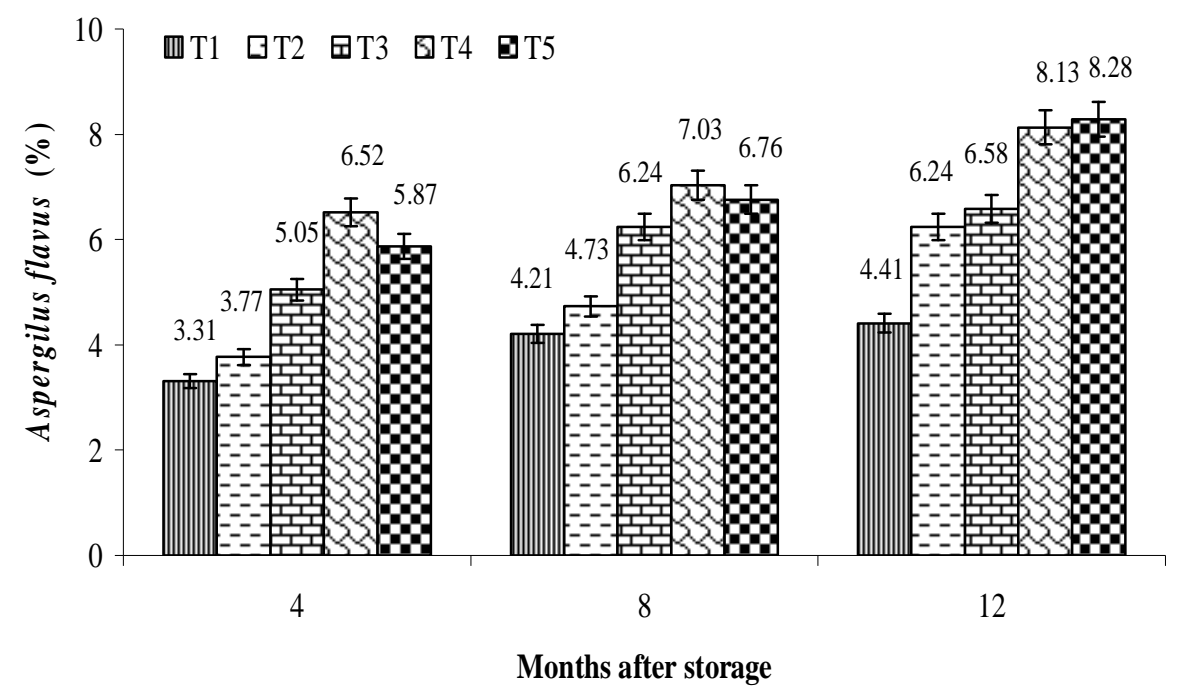

( $\mathrm{T}_{1}$ : Plastic container; $\mathrm{T}_{2}$ : Plastic bag; $\mathrm{T}_{3}$ : Polythene coated gunny bag; $\mathrm{T}_{4}$ : Gunny bag and $\mathrm{T}_{5}$ : Earthen pot)

Figure 2. Effect of storage containers on the prevalence (\%) of Aspergilus flavus (\%) of okra seeds at different months of storage 


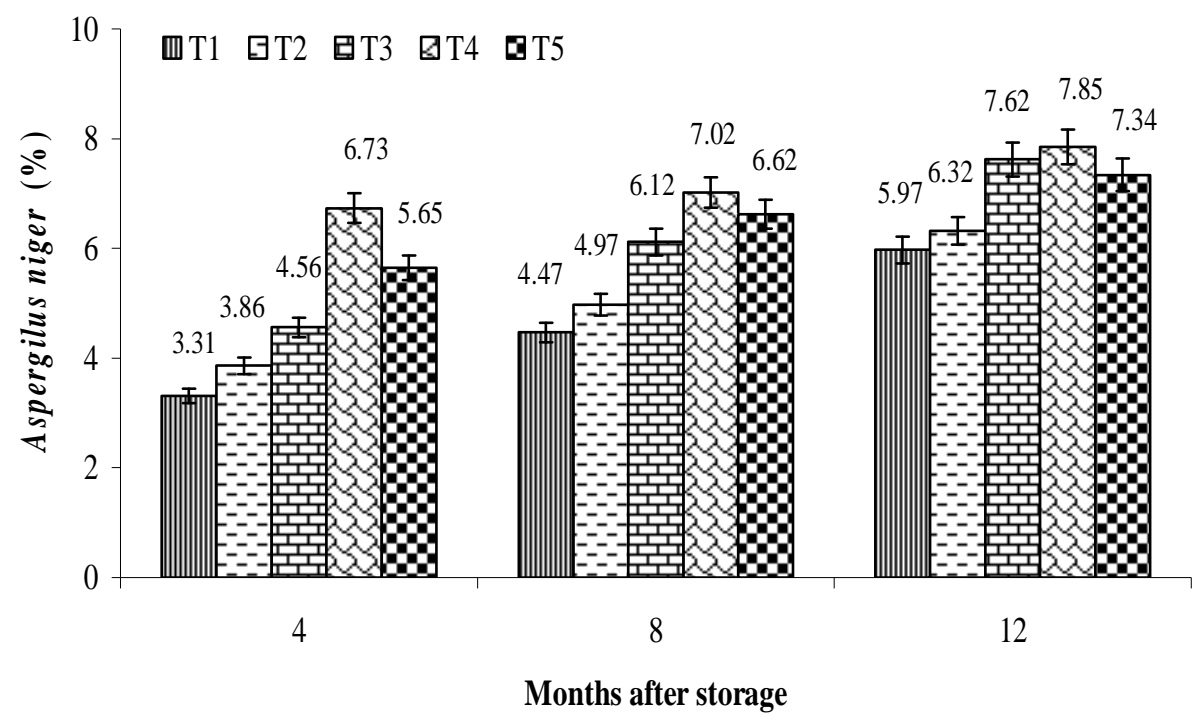

( $\mathrm{T}_{1}$ : Plastic container; $\mathrm{T}_{2}$ : Plastic bag; $\mathrm{T}_{3}$ : Polythene coated gunny bag; $\mathrm{T}_{4}$ : Gunny bag and $\mathrm{T}_{5}$ : Earthen pot)

Figure 3. Effect of storage containers on the prevalence (\%) of Aspergilus niger (\%) of okra seeds at different months of storage

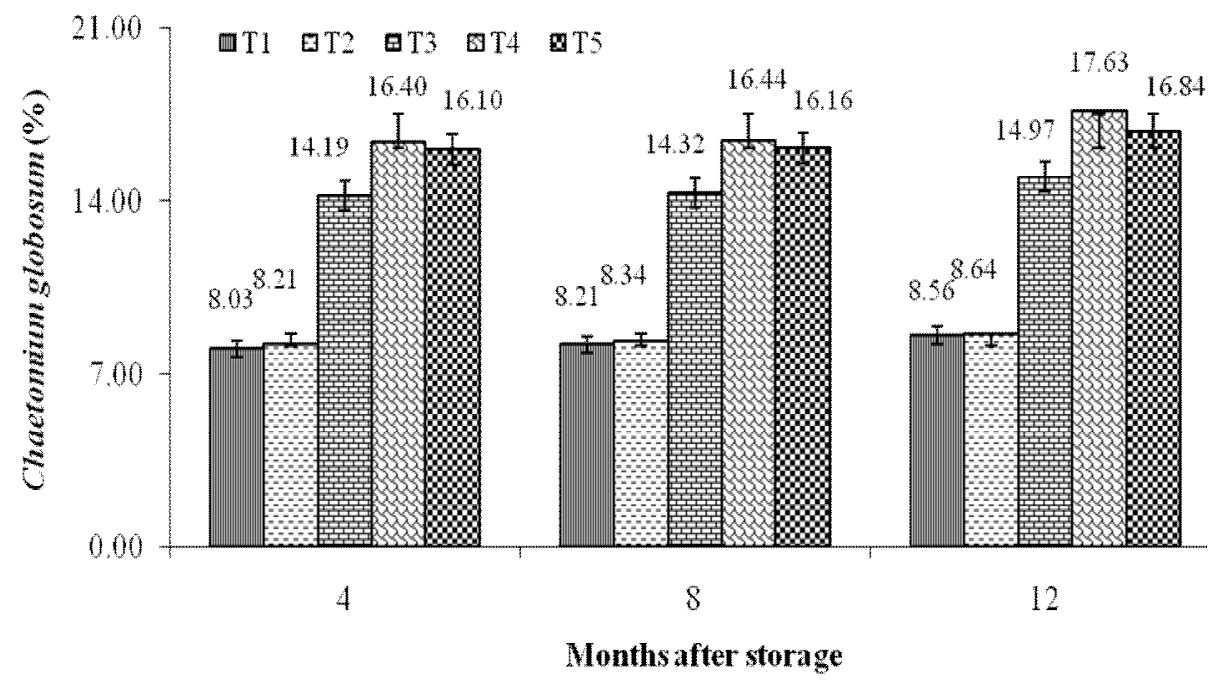

( $\mathrm{T}_{1}$ : Plastic container; $\mathrm{T}_{2}$ : Plastic bag; $\mathrm{T}_{3}$ : Polythene coated gunny bag; $\mathrm{T}_{4}$ : Gunny bag and $\mathrm{T}_{5}$ : Earthen pot)

Figure 4. Effect of storage containers on the prevalence (\%) of Chaetomium globosum of okra seeds at different months of storage 


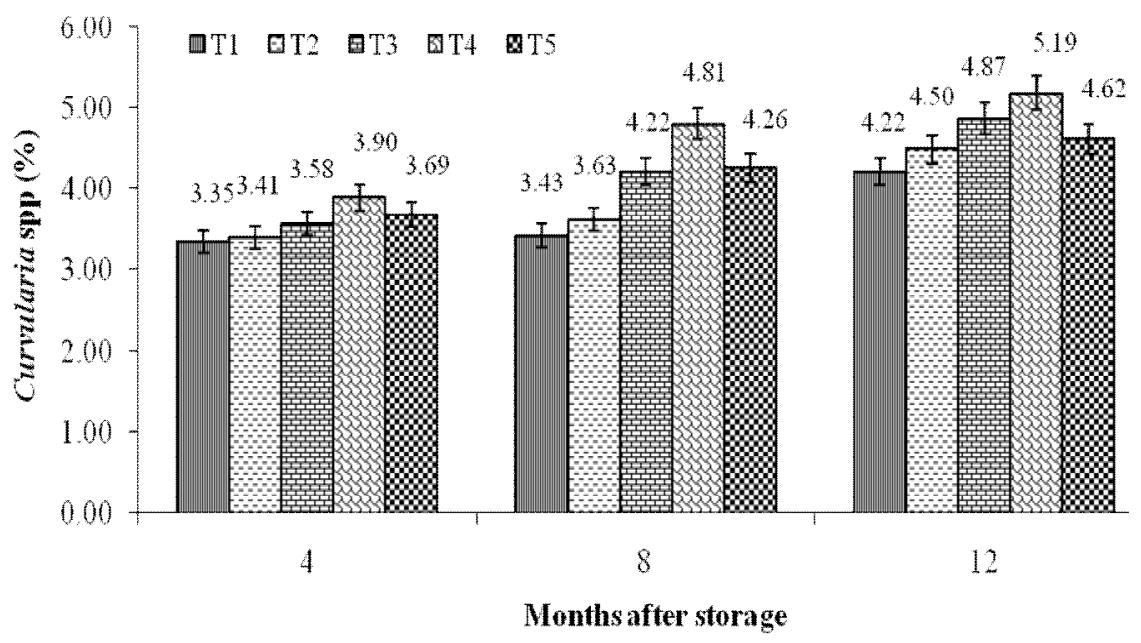

( $\mathrm{T}_{1}$ : Plastic container; $\mathrm{T}_{2}$ : Plastic bag; $\mathrm{T}_{3}$ : Polythene coated gunny bag; $\mathrm{T}_{4}$ : Gunny bag and $\mathrm{T}_{5}$ : Earthen pot) Figure 5. Effect of storage containers on the prevalence (\%) of Curvularia spp. of okra seeds at different months of storage

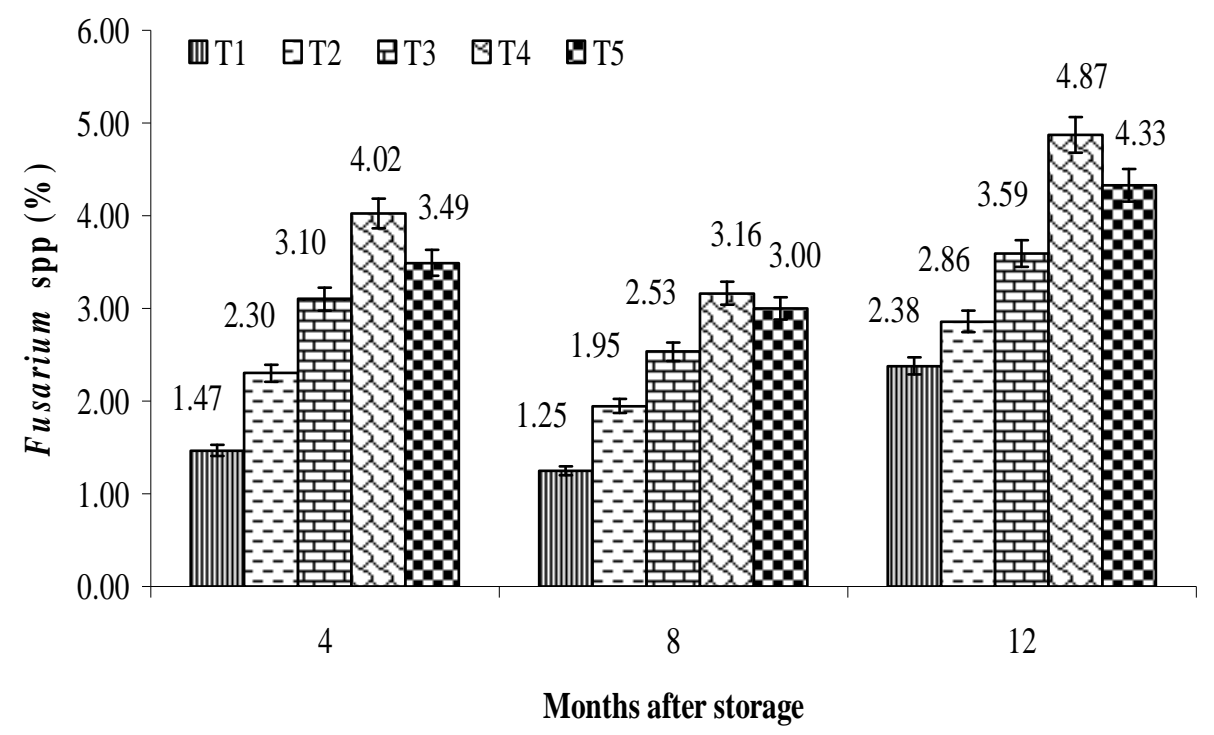

$\mathrm{T}_{1}$ : Plastic container; $\mathrm{T}_{2}$ : Plastic bag; $\mathrm{T}_{3}$ : Polythene coated gunny bag; $\mathrm{T}_{4}$ : Gunny bag and $\mathrm{T}_{5}$ : Earthen pot)

Figure 6. Effect of storage containers on the prevalence (\%) of Fusarium spp. of okra seeds at different months of storage 


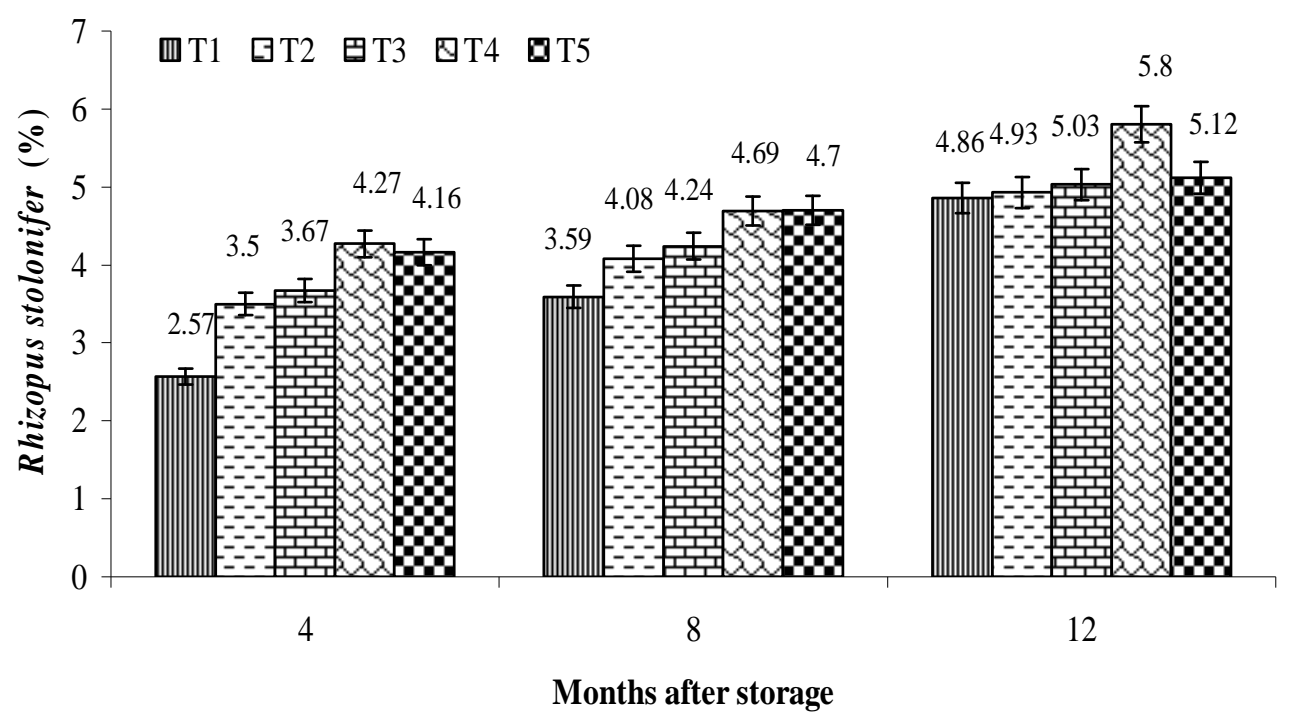

( $\mathrm{T}_{1}$ : Plastic container; $\mathrm{T}_{2}$ : Plastic bag; $\mathrm{T}_{3}$ : Polythene coated gunny bag; $\mathrm{T}_{4}$ : Gunny bag and $\mathrm{T}_{5}$ : Earthen pot)

Figure 7. Effect of storage containers on the prevalence (\%) of R. stolonifer (\%) of okra seeds at different months of storage

\section{Conclusions}

The lowest population of fungal prevalence and moisture content associated with minimum germination, field emergence, seedling vigor index, and shoot and root growth were recorded when seeds were stored in plastic pots followed by earthen pot and gunny bag. The present study revealed that plastic pot container is the best to store okra seeds.

\section{References}

Abdul-Baki, A.and Anderson, J. D. 1973. Vigor determination in Soybean seed by multiple criteria. Crop Science, 13: 630633.

Aktaruzzaman, M., Azad, M. O. K., Shiton, A. K. R., Mottakina, A. M. and Habiba. M. 2010. Effect of biotic and abiotic factors on quality of okra seed kept in different containers. Bangladesh Research and Publication Journals, 3(2): 1012-1020.

Anonymous, 2003. Indian Agriculture. Vikas Singhal for Indian Economic Data Research Centre, Maya Puri, New Delhi, India. 271-272 pp.

Anonymous, 2010. Annual progress report of okra cultivation. Bangladesh Agricultural Research Institute, Gazipur, Bangladesh. 45-86 pp.

Anonymous, 2012. Summary of crop statistics and crop indices (2010-11). Bangladesh Bureau of Statistics Division, Govt. of the People's Republic of Bangladesh. 9 p.

Badaru, O. 2011. The effect of Moringa oleifera (Moringa species) leaf extract on germination and fungal growth of Abelmoschus esculentus L. (Okra). B.Sc. Dissertation, Babcock University, Nigeria. 
Begum, M., Lokesh, S., Ravishankar, R.V., Shailaja, M.D ,Kumar, T.V. and Shetty, H.S. 2005. Evaluation of certain storage conditions for okra (Abelmoschus esculentus L. Moench) seeds against potential fungal pathogens. Journal of Agriculture and Biology, 7(4): 550-554.

Fabunmi, O. A. 2009. Effects of packaging materials and storage temperature on quality of fresh okra (Abelmoschus esculentus) fruit. Agricultura Tropica Et Subtropica, 42(4): 151-156.

Fakir, G. A. 2001. An annotated list of seed borne disease in Bangladesh. Seed Pathology Laboratory. Department of Plant Pathology, Bangladesh Agricultural University. Mymensingh, $41 \mathrm{p}$.

Gopalan, C., Rama Sastri, B. V. and Balasubramanian, S. 2007. Nutritive Value of Indian Foods. National Institute of Nutrition (NIN), ICMR.

Islam, M. Z. 2006. Effect of seed treatment with Mehagoni seed and Neem extract on the prevalence of seed-borne pathogens of okra. MS Thesis, Department of Plant Pathology, Bangladesh Agricultural University (BAU), Mymensingh.
Jamadar, M. M., Ashok, S., Shamrao, J., Sajjan, A. and Jahangidar, S. 2001. Studies on seed mycoflora and their effect on germination of colour graded okra [Abelmoschus esculentus (L.) Moench]. Journal of Crop Research (Hisar), 22 (3): 479-484.

Khalekuzzaman, K.M., Rashid, M.M., Hasan, M.A.and Reza, M.M.A. 2012. Effect of storage containers and storage period on seed quality of French bean. Bangladesh Journal of Agricultural Research, 37(2):195-2005.

Malaker, P.K., Mian, I.H., Bhuiyan, K.A., Akanda, A.M., Reza, M.M.A. 2008. Effect of storage containers and times on seed quality of wheat. Bangladesh Journal of Agricultural Research, 33(3):469-477.

Monira, U. S., Amin, M. H. A., Aktar, M.M., Mamun, M. A. A. 2012. Effect of containers on seed quality of storage soybean seed. Bangladesh Research Publication Journals, 7(4): 421-427.

Nwangburuka, C. C. 2010. Morphological characterization and genetic studies in okra [Abelmoschus esculentus (L. 0 Moench]. PhD Thesis, University of Agriculture Abeokuta, Nigeria. 